\title{
Temporal and within-plant distribution of the parasitoid and predator complexes associated with Acyrthosiphon pisum and $A$. kondoi (Homoptera: Aphididae) on alfalfa in Japan
}

\author{
Yoshitaka NaKashima* and Masako AKashi \\ Laboratory of Entomology, Obihiro University of Agriculture and Veterinary Medicine; Obihiro, Hokkaido 080-8555, Japan \\ (Received 5 April 2004; Accepted 4 October 2004)
}

\begin{abstract}
Seasonal abundance and within-plant distribution of Acyrthosiphon spp. and their natural enemies were investigated on alfalfa in Obihiro, Hokkaido, Japan in 2001. Densities of A. pisum and A. kondoi peaked in early June. Coccinellid and syrphid predators appeared to respond to aphid numbers and were synchronized with aphid populations. Two species of braconid (aphidiine) parasitoids (Aphidius ervi and Praon barbatum) were collected. Parasitism rates for each aphid species were variable through the season, but the estimated number of parasitized aphids reached a peak at the same time as overall aphid densities. After the first harvesting of alfalfa (14 June) aphid densities became very low, and coccinellid and syrphid predators were not found. In contrast to the coccinellid and syrphid predators, the heteropteran predators, Nabis stenoferus and Orius spp. became common during summer. Aphids, immature parasitoids (live parasitized aphids and mummies), Coccinella septempunctata and syrphids occurred more on the upper parts of alfalfa stems than on the lower parts, but this trend was not found for Hippodamia tredecimpunctata. The temporal and spatial distributions of members of the aphidphagous guild are likely to influence natural enemy-aphid relationships and intraguild interactions.
\end{abstract}

Key words: Aphidius ervi; Coccinella septempunctata; hyperparasitoid; intraguild interaction; Praon barbatum

\section{INTRODUCTION}

The pea aphid, Acyrthosiphon pisum (Harris), and the blue alfalfa aphid, A. kondoi Shinji (Homoptera: Aphididae), are serious pests of alfalfa, Medicago sativa L., and other leguminous crops in many parts of the world (Stern et al., 1980; Summers and Coviello, 1984; Lenssen et al., 1991; Lane and Walters, 1991). Their infestation causes deformation of leaves and stunting of the plants (Schepers, 1989; Cuperus et al., 1982), and they are also vectors of plant viruses (Sylvester, 1989; Bosque Perez and Buddenhagen, 1990). These aphids are associated with a large assemblage of insect natural enemies such as Hymenopteran parasitoids, and Coccinellid, Syrphid, Nabid, Anthocorid, and Chrysopid predators (Mackauer and Finlayson, 1967; Takada, 1968; Wheeler, 1977; Ekbom, 1994; Brodeur and Rosenheim, 2000).

The ladybird beetle Coccinella septempunctata
L. (Ekbom, 1994) and the braconid parasitoids Aphidius ervi Haliday and Praon barbatum Mackauer are reported as important natural enemies of Acyrthosiphon species on alfalfa (Carver, 1989; Hughes, 1989; Takahashi, 1996; Milne, 1999; Senoo et al., 2002). However, the temporal and spatial distribution of the whole natural enemy complex in relation to the aphids is not clearly understood at present.

The degrees of temporal and spatial associations between the target pest and each natural enemy species are likely to influence the ability of a natural enemy to suppress the pest population. Furthermore, similarities in the temporal and spatial distributions of different members of the natural enemy guild are important for inferring intraguild relationships, which may be useful for understanding the indirect effects of intratrophic predator interactions on aphid population dynamics. For instance, intraguild predation (IGP), trophic interactions

\footnotetext{
* To whom correspondence should be addressed at: E-mail: nksm@obihiro.ac.jp
} DOI: $10.1303 / \mathrm{aez} .2005 .137$ 
between natural enemies sharing the same resource, may be common in agroecosystems and may influence the level of herbivore population suppression (Rosenheim et al., 1993, 1995; Rosenheim, 1998; Raymond et al., 2000). Interactions between various combinations of intraguild natural enemies associated with aphids are known, such as IGP between parasitoids (Mackauer, 1990), between predators (Wheeler, 1977; Atim and Graham, 1984), between predators and parasitoids (Wheeler et al., 1968; Colfer and Rosenheim, 1995; Wells et al., 2001; Nakashima and Senoo, 2003; Nakashima et al., 2004) and between entomopathogens and parasitoids (Powell et al., 1986; Brooks, 1993). Thus, identifying the spatio-temporal patterns of each member of an aphidophagous guild is important to assess the functional role of the guild in controlling aphid abundance.

To determine temporal and spatial relationships among aphids and their natural enemy complex, we measured aphid and predator abundance and levels of parasitism of two Acyrthosiphon species in an alfalfa field. We also investigated the patterns of within-plant distribution of aphids, immature parasitoids (live parasitized aphids and mummies) and the major predator species. The roles of parasitoid and predator complexes in the suppression of aphid populations and possible intraguild interactions are discussed.

\section{MATERIALS AND METHODS}

Field site. Field studies were conducted throughout the 2001 growing season in an alfalfa field (4 ha) at Obihiro University of Agriculture and Veterinary Medicine in Obihiro $\left(42^{\circ} 92^{\prime} \mathrm{N}\right.$, $143^{\circ} 22^{\prime} \mathrm{E}$ ), Hokkaido, Japan. No insecticides were used in the field. The alfalfa was harvested on 13 June, 29 July and 19 September in 2001.

Seasonal abundance. Samples were obtained approximately every $10 \mathrm{~d}$ from 12 May to 17 November 2001. Ten sweeps within a $1 \mathrm{~m} \times 1 \mathrm{~m}$ quadrat were taken with a $40 \mathrm{~cm}$ diameter sweepnet at 15 random locations within the alfalfa field on each sampling date. The heights of five selected stems of alfalfa in each quadrat were also measured to monitor the growth rate of the alfalfa crop. Sweep samples were kept in plastic boxes $(28 \times 13$ $\times 7 \mathrm{~cm}$ ), placed in coolers with ice, and transported to the laboratory for sorting and counting the num- bers of aphids and their natural enemies present. Potential insect predators of $A$. pisum and A. kon$d o i$, such as coccinellid larvae and adults and hemipteran (Nabidae and Anthocoridae) adults were identified. Neuropteran larvae were not identified to species. To identify the species of syrphid larvae, those collected from the field on 5 June were reared until adult emergence in a growth room at $20 \pm 1{ }^{\circ} \mathrm{C}$ and a photoperiod of $16 \mathrm{~L}: 8 \mathrm{D}$. These larvae were reared in $9 \mathrm{~cm}$ diameter Petri dishes, and provided with 100-200 A. pisum as food, which was replaced every $2 \mathrm{~d}$ until pupation.

Parasitism rates of $A$. pisum and $A$. kondoi were evaluated by rearing live aphid samples in the laboratory. The aphids were reared on broad bean seedlings, Vicia fabae L. (Fabaceae) (var. minor), at the 4 to 6-leaf stage, in plant pots measuring $7.0 \mathrm{~cm}$ in height and $5.5 \mathrm{~cm}$ in diameter at the bottom and $7.5 \mathrm{~cm}$ in diameter at the top. Each pot contained 3-4 seedlings, grown in vermiculite, and was kept in a cylindrical acrylic tube (diameter $8.5 \mathrm{~cm}$, height $25.0 \mathrm{~cm}$ ) with the top covered by mesh to enclose the infested seedlings securely.

For each sampling unit, each aphid species (A. pisum or A. kondoi) was separately transferred to the plants with a fine paintbrush. In general, 30 randomly selected aphids of each species were transferred per sampling unit, whilst all aphids were transferred when the number of aphids was less than 30 . The rate of parasitism for each sample unit was estimated by dividing the number of mummified aphids that developed by the number of reared aphids. Plants with aphids were maintained for $10-14 \mathrm{~d}$ in a growth room at $20 \pm 1^{\circ} \mathrm{C}$ and a photoperiod of $16 \mathrm{~L}: 8 \mathrm{D}$.

Within-plant distribution. To evaluate the vertical distribution of predators and unparasitized and parasitzed aphids, insects were collected from two strata of alfalfa stems in 20, randomly chosen, quadrats $(1 \mathrm{~m} \times 1 \mathrm{~m})$ in the field. In each quadrat, 15 , randomly selected, alfalfa stems were cut $25 \mathrm{~cm}$ from the base of the stem and at the base (the alfalfa stem heights were $50.1 \mathrm{~cm}$ on average). The upper and lower stems taken from each quadrat were placed separately in boxes $(15 \times 10 \times 5 \mathrm{~cm})$ and transported to the laboratory. Aphids and predators on each stratum were counted, and aphids collected from each part of the plant were reared on broad bean seedlings to estimate rates of parasitism as described above. Sampling was done 
on 4 and 5 June 2001 when aphids were most abundant.

To characterize the vertical distribution of mummies that contained either primary parasitoids or hyperparasitoids, 100 alfalfa stems were randomly selected and cut at the base. The height of each alfalfa stem and the height at which mummies were present were recorded. Collected mummies were labeled and kept individually in gelatine capsules at $20 \pm 1{ }^{\circ} \mathrm{C}$ and a photoperiod of $16 \mathrm{~L}: 8 \mathrm{D}$ until adult emergence, when emerged primary parasitoids and hyperparasitoids were identified. The sampling was conducted on 12 June.

Data analysis. Insect densities and rates of parasitism were analyzed using the Mann-Whitney $U$ test and Wilcoxon's signed rank test. Densities of predator species on upper and lower halves of alfalfa stems were compared using the Mann-Whitney $U$ test with correction (the sequential Bonferroni method; Rice, 1989). The heights of primary parasitoid and hyperparasitoid mummies on the plants were compared using the Kruskal Wallis test. All tests were conducted with a 5\% level of significance.

\section{RESULTS}

Densities of $A$. pisum and A. kondoi increased during May and early June and peaked on 4 June. After the first harvest, the population density decreased and remained low until the end of the season $\left(0-4.4\right.$ and $0-3.3 / \mathrm{m}^{2}$ for $A$. pisum and $A$. $k o n d o i$, respectively) (Fig. 1). On the first three sampling dates, densities of $A$. kondo $i$ were significantly higher than those of $A$. pisum (Mann-Whitney $U$ test, $p<0.05$ ), but no difference was found on subsequent dates.

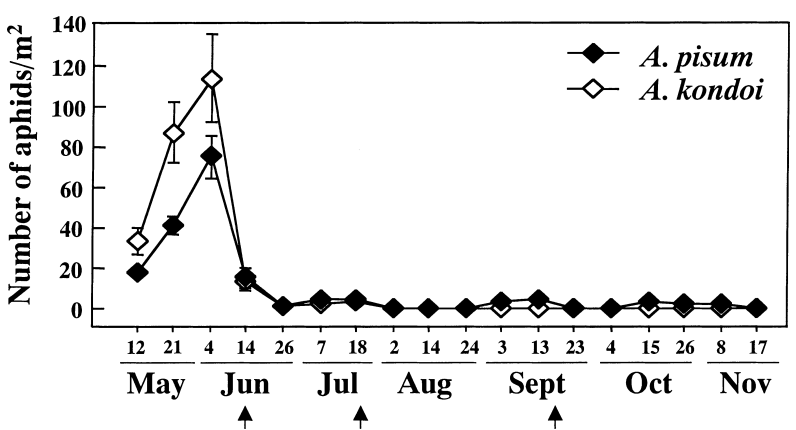

Fig. 1. Changes in densities of Acyrthosiphon pisum and A. kondoi. Arrows below calendar and bars with plots indicate days of harvesting and SE, respectively.
Natural enemies collected in the survey are shown in Table 1. Parasitism rates of A. pisum by $A$. ervi at the beginning of the season (early May) reached $31 \%$ (Fig. 2). The rates due to A. ervi were higher than those caused by $P$. barbatum throughout the season, for both $A$. pisum and $A$. kondoi

Table 1. Natural enemies of Acyrthosiphon pisum and A. kondoi collected in the alfalfa field in Hokkaido, Japan

\begin{tabular}{|c|c|}
\hline $\begin{array}{l}\text { Family of predators } \\
\text { and parasitoids }\end{array}$ & Species of predators or parasitoids \\
\hline \multicolumn{2}{|l|}{ Parasitoids: } \\
\hline Aphididae & $\begin{array}{l}\text { Aphidius ervi Haliday } \\
\text { Praon barbatum Mackauer }\end{array}$ \\
\hline \multicolumn{2}{|l|}{ Predators: } \\
\hline Coccinelidae & $\begin{array}{l}\text { Coccinella septempunctata } \mathrm{L} . \\
\text { Hippodamia tredecimpunctata } \text { Capra } \\
\text { Propylea quatuordecimpunctata }(\mathrm{L} .)^{\mathrm{b}}\end{array}$ \\
\hline Syrphidae $^{c}$ & $\begin{array}{l}\text { Metasyrphus (Eupeodes) } \\
\quad \text { corollae (Fabricius) } \\
\text { Episyrphus balteatus (de Geer) } \\
\text { Metasyrphus ferquens Matsumura } \\
\text { Syrphus vitripennis Meigen }\end{array}$ \\
\hline Anthocoridae & $\begin{array}{l}\text { Orius sauteri Poppius } \\
\text { Orius minutus L. }\end{array}$ \\
\hline Nabidae & Nabis stenoferus Hisao \\
\hline
\end{tabular}

${ }^{\text {a }}$ Five Neuropteran larvae were sampled in July and September, but not identified.

${ }^{\mathrm{b}}$ Two adults were sampled in June.

${ }^{c}$ Adults were reared from field collected larvae.

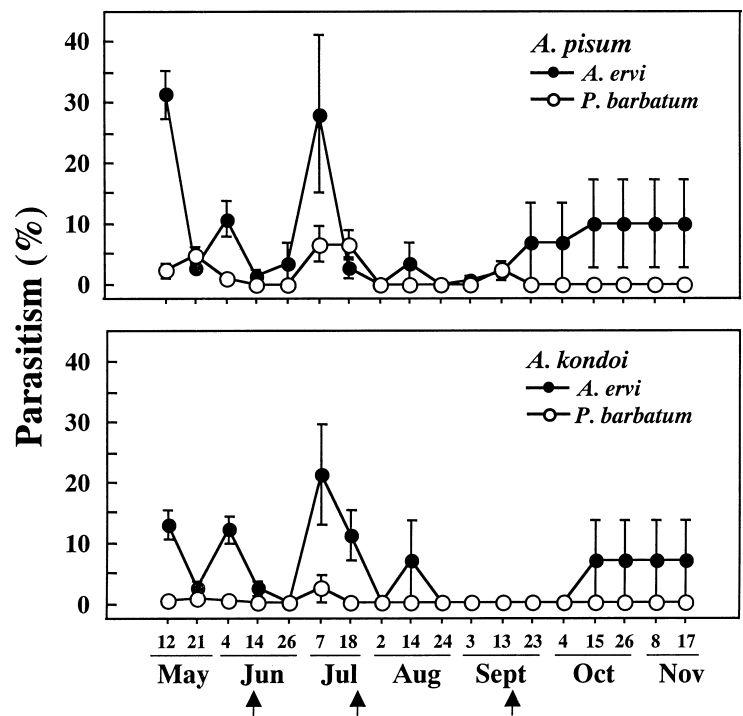

Fig. 2. Changes in parasitism rates of Acyrthosiphon pisum and A. kondoi by Aphidius ervi and Praon barbatum. Arrows and bars indicate days of harvesting and SE, respectively. 


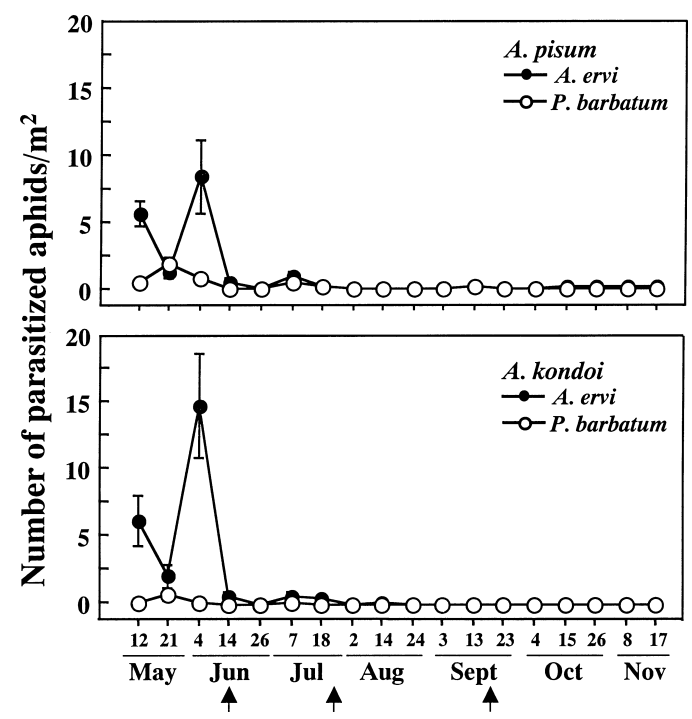

Fig. 3. Changes in estimated densities of Acyrthosiphon pisum and A. kondoi parasitized by Aphidius ervi and Praon barbatum. Arrows and bars indicate days of harvesting and $\mathrm{SE}$, respectively.

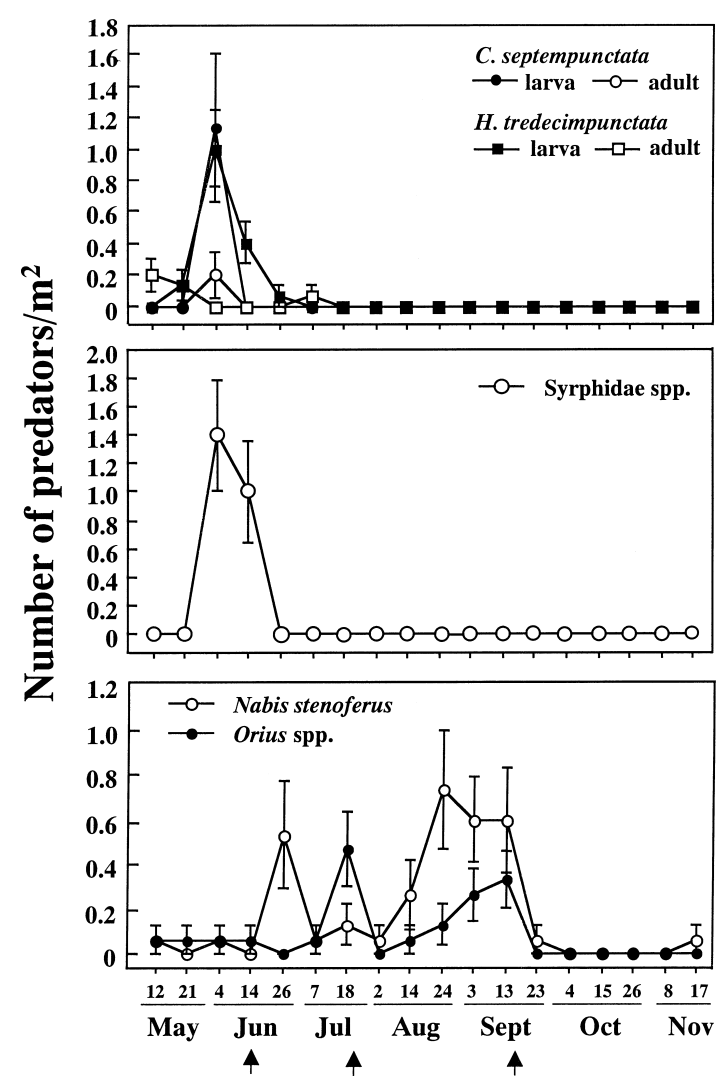

Fig. 4. Changes in densities of predators, coccinellids (top), syrphids (middle), and heteropterans (bottom). Arrows and bars indicate days of harvesting and SE, respectively.
(Mann-Whitney $U$ test, $p<0.05$ ). Estimated numbers of aphids parasitized by $A$. ervi and P. barbatum were also restricted in this period (Fig. 3). After the first harvest, parasitism rates due to A. ervi varied over the season (Fig. 2). Occurrence of coccinellids (C. septempunctata and Hippodamia tredecimpunctata Capra) and syrphids (larvae) were limited during late May and early June (Fig. 4). In contrast to coccinellids and syrphids, heteropteran predators were abundant from late June to late September when the aphid population was small (Figs. 1 and 4).

Within-plant distributions of aphids and immature parasitoids (live parasitized aphids) were concentrated in the upper half of alfalfa stems (Fig. 5). Aphidius ervi was the only parasitoid species found in this part of the investigation. Both the number of parasitized aphids and rates of parasitism were also greater in the upper half of the plant for each aphid species (Wilcoxon's signed rank test, $p<0.01$ ) (Fig. 5). Also, all mummies of $A$. ervi were on the upper half of the stem. The average height of alfalfa stems was $64.3 \pm 1.2 \mathrm{~cm}($ mean $\pm \mathrm{SE}, n=100)$ on 12 June. Dendrocerus carpenteri (Curtis)

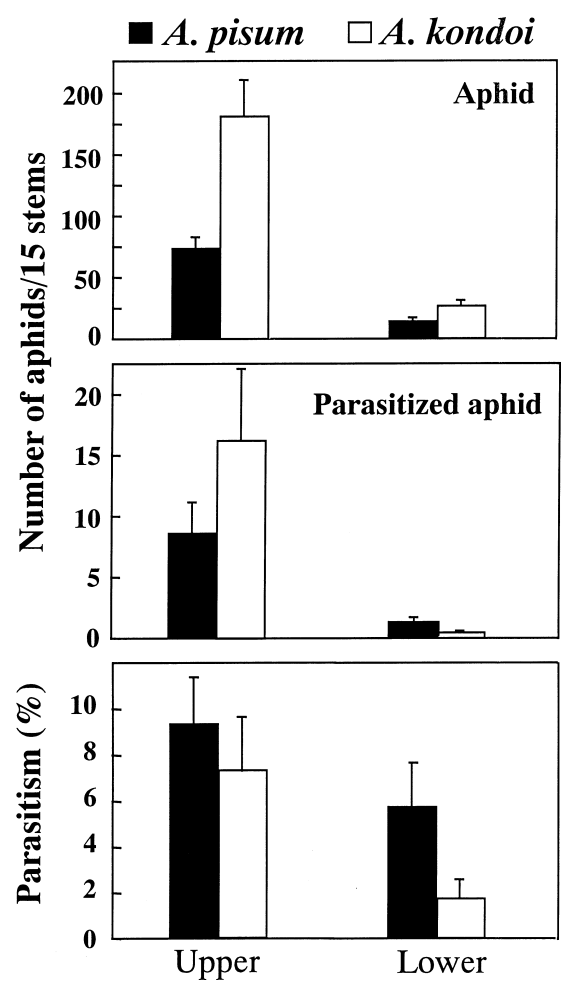

Fig. 5. Numbers of aphids (top) and parasitized aphids (middle), and rates of parasitism (bottom) in lower $(<25 \mathrm{~cm})$ and upper $(>25 \mathrm{~cm})$ parts of alfalfa stems. Bars indicate SE. 


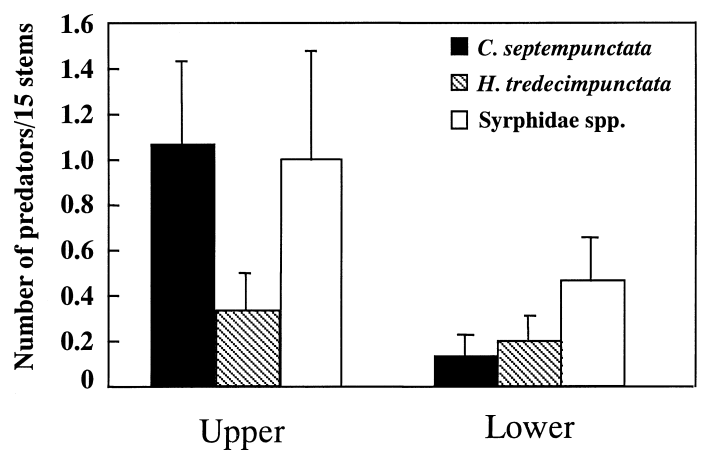

Fig. 6. Number of predators in lower $(<25 \mathrm{~cm})$ and upper $(>25 \mathrm{~cm})$ parts of alfalfa stems. Bars indicate SE.

(Megaspilidae) and Asaphes suspensus (Nees) (Pteromalidae) emerged from $A$. ervi mummies. Average heights on the plant of mummies containing $A$. ervi, D. carpenteri and $A$. suspensus were $50.86 \pm 2.0 \mathrm{~cm}(n=62), 54.5 \pm 7.4 \mathrm{~cm}(n=9)$ and $48.6 \pm 3.0 \mathrm{~cm}(n=21)$, respectively. These heights for the different species were not significantly different (Kruskal Wallis test, $p>0.05$ ).

Within-plant distributions were variable amongst predator species (Fig. 6). Numbers of C. septempunctata and syrphid species (larvae) were significantly greater on the upper parts of alfalfa stems (Wilcoxon's signed rank test, $p<0.01$ ). On the other hand, no significant difference between upper and lower parts of the stem in the number of $\mathrm{H}$. tredecimpunctata was found (Wilcoxon's signed rank test, $p>0.05$ ). Within the upper part of the stems, there were significantly more $C$. septempunctata than $H$. tredecimpunctata (Mann-Whitney $U$ test with correction of the sequential Bonferroni method, $p<0.05$ ), but there were no significant differences between the numbers of $C$. septempunctata and syrphidae species or between numbers of H. tredecimpunctata and syrphidae species. Within the lower half of the plant, statistically similar numbers of ladybirds and syrphids were recorded.

\section{DISCUSSION}

Numbers of $A$. pisum and $A$. kondoi were restricted during May and early June (Fig. 1). The low aphid densities during summer were probably because of decreased reproduction due to high temperatures (Siddiqui et al., 1973; Takahashi, 1996). The aphid population trend up until summer was roughly consistent with that recorded in an earlier survey in 2000 (Senoo et al., 2002). An increase in aphid densities during autumn, however, was not found in this survey, although previous studies showed that another peak normally appears from October to November (Takahashi, 1996; Senoo et al., 2002). We are unsure of the reason for this difference, but we note that higher rates of parasitism by $A$. ervi during summer and autumn, 2001 (20-30\% in July and 8-10\% in autumn) may have prevented a second increase in aphid numbers (Fig. 2). In contrast, parasitization by A. ervi was scarce from summer to the end of the season in the earlier survey (Senoo et al., 2002).

Parasitism rates of $A$. pisum by $A$. ervi at the beginning of the season were relatively high (Fig. 2). This parasitization, probably due to adults of the overwintering generation, would have had a significant impact on the initial aphid density. The parasitism during this part of the season may contribute to decreasing the initial number of aphids colonising crops the following spring. Comparison with data from our previous survey suggests that the dominant parasitoid species can change from year to year. The parasitism due to P. barbatum was three times higher than that caused by $A$. ervi at the peak in June 2000 (Senoo et al., 2002).

Seasonal distributions of predator species were divided into two distinct phases. Number of coccinelids and syrphids (larvae) were restricted during May and June. Ladybird species were also dominated by $C$. septempunctata and H. tredecimpunctata in the previous year, but syrphid populations appear to be more variable from year to year because few were collected in 2000 compared with 2001 (Nakashima, unpublished data). Nabis and Orius predators are common in alfalfa fields, and appear during summer when aphid densities are very low (Nielson and Henderson, 1959; Wheeler, 1977), as shown in this study. These groups were considered to be less effective predators on the basis of their feeding capacities against aphids (Nielson and Henderson, 1959), and are regarded as polyphagous predators (Wheeler, 1977; Nagai, 1993). Nagai (1993) suggested that aphids are sub-optimal prey for Orius species. Although $N$. stenoferus and the two Orius species may help to delay a new build up of the aphid population, relationships with other prey species in alfalfa need be determined.

Within-plant distributions of aphids and imma- 
ture parasitoids (live parasitized aphids) were concentrated in the upper half of alfalfa stems (Fig. 5). This distribution pattern was probably due to the preference of these aphids for young alfalfa leaves or buds because the upper part of the plant is where new buds arise, and younger leaves usually have a higher concentration of primary metabolites (e.g. Merritt, 1996). Also, all mummies of $A$. ervi were on the upper half of the stems. These results suggest that adult parasitoids allocate more foraging time in the upper parts of alfalfa plants and parasitized aphids predominantly mummified there.

Differences in vertical distribution amongst aphidophagous coccinellids may occur due to microhabitat preferences (Ewert and Chiang, 1966; Hemptinne et al., 1988) or interference between predator species (Schellhorn and Andow, 1999). It is not clear, however, whether the different patterns of within-plant distribution between the two ladybird species in our study were due to their microhabitat preferences or mutual interference.

In this crop system, aphid densities are high over a limited period (late May and early June) (Fig. 1 and Senoo et al., 2002). Thus, members of the aphidophagous guild occurring during this economically important period seem to play an important role in aphid suppression. Our data suggest that $A$. ervi, C. septempunctata and syrphids contribute to suppression of the aphid population significantly more than other species because of their abundance and the similarity of their temporal and spatial distribution patterns to those of the aphids. The temporal aggregation of some species of natural enemies may be caused by attraction to induced plant volatiles emitted after aphids have damaged the alfalfa. Aphidius ervi (Du et al., 1998; Powell et al., 1998) and C. septempunctata (Ninkovic et al., 2001) were reported to be attracted to herbivore-induced volatiles. The aggregation of the parasitoid and predator guild may play an important role in the population dynamics of aphids before the first harvest.

A high degree of temporal and spatial overlap in the distributions of a number of natural enemies may increase intraguild interactions. Such interactions could be critical events in the population dynamics of aphids, because they may indirectly affect suppression of aphid populations by aphidophagous guilds. For instance, it is reported that intraguild predation negatively affects biological control of aphid populations (Colfer and Rosenheim, 1995; Ferguson and Stiling,1996; Yasuda and Shinya, 1997). However, intraguild interactions sometimes facilitate aphid suppression (Losey and Denno, 1998, 1999). From the results of our survey, these types of interaction may occur among $A$. ervi, $C$. septempunctata and syrphids. Acyrthosiphon pisum parasitized by $A$. ervi are also consumed by $C$. septempunctata (Nakashima, unpublished data) as in other parasitoid-predator systems (Wheeler et al., 1968; Takizawa et al., 2000; Wells et al., 2001). The direction and intensity of intraguild interactions in limited time and space need to be determined for further understanding of the role of the whole aphidophagous guild in biological aphid control.

\section{ACKNOWLEDGEMENTS}

We would like to thank Drs. H. Takada and T. Yasunaga for identifying parasitoids and heteropteran predators, respectively. Thanks are also due to Prof. W. Powell for valuable comments and discussion. We have appreciated the support from the staff at the University farm. This work was supported by a Research Fellowship (to Y.N.) through the Japan Society for the Promotion of Science.

\section{REFERENCES}

Atim, A. B. and H. M. Graham (1984) Predation of Geocoris punctipes by Nabis alternatus. Southwest. Entomol. 13: 882-887.

Bosque Perez, N. A. and I. W. Buddenhagen (1990) Studies on epidemiology of virus disease of chickpea in California. Plant Disease 74: 372-378.

Brodeur, J. and J. A. Rosenheim (2000) Intraguild interactions in aphid parasitoids. Entomol. Exp. Appl. 97: 93108.

Brooks, W. M. (1993) Host-parasitoid-pathogen interactions. In Parasites and Pathogens of Insects (N. E. Beckage, S. N. Thompson and B. A. Federici eds.). Academic Press, San Diego, CA, pp. 231-272.

Carver, M. (1989) Biological control of aphids. In Aphids: Their Biology, Natural Enemies and Control. Vol. 2C (A. K. Minks and P. Harrewijn eds.). Elsevier, Amsterdam, pp. 141-165.

Colfer, R. G. and J. A. Rosenheim (1995) Intraguild predation by coccinellid beetles on an aphid parasitoid, Lysiphlebus testaceipes. Proc. Beltwide Cotton Conf. 9: 1033-1036.

Cuperus, G. W., E. B. Radcliffe, D. K. Barnes and G. C. Marten (1982) Economic injury levels and economic threshold for pea aphids, Acyrthosiphon pisum (Harris), on alfalfa. Crop Protection 1: 453-463.

Du, Y. J., G. M. Poppy, W. Powell, J. A. Pickett, L. J. Wadhams and C. M. Woodcock (1998) Identification of semio- 
chemicals released during aphid feeding that attract parasitoid Aphidius ervi. J. Chem. Ecol. 24: 1355-1368.

Ekbom, B. (1994) Arthropod predators of the pea aphid, Acyrthosiphon pisum Harr. (Hom., Aphididae) in peas (Pisum sativum L.), clover (Trifolium pratense L.) and alfalfa (Medicago sativa L.). J. Appl. Entomol. 117: 469476.

Ewert, M. A. and H. C. Chiang (1966) Effects of some environmental factors on the distribution of three species of Coccinellidae in their microhabitat. In Ecology of Aphidophagous Insects (I. Hodek ed.). Academia, Prague and Dr. W. Junk, The Hague, pp. 195-219.

Ferguson, K. I. and P. Sitling (1996) Non-additive effects of multiple natural enemies on aphid populations. Oecologia 108: 375-379.

Hemptinne, J.-L., J. Naisse and S. Os (1988) Glimpse of the life history of Propylea quatuordecimpunctata (L.) (Coleoptera: Coccinellidae). Med. Fac. Ladbouww. Rijksuniv. Gent. 53: 1175-1182.

Hughes, R. D. (1989) Biological control in the open field. In Aphids: Their Biology, Natural Enemies and Control. Vol. 2C (A. K. Minks and P. Harrewijn eds.). Elsevier, Amsterdam, pp. 167-198.

Lane, A. and K. F. A. Walters (1991) Effect of pea aphid (Acyrthosiphon pisum) on the yield of combining peas. Asp. Appl. Biol. 27: 363-368.

Lenssen, A. W., E. L. Sorensen, G. L. Posler and S. L. Blodgett (1991) Depression of forage quality of alfalfa leaves and stems by Acyrthosiphon kondoi (Homoptera: Aphididae). Environ. Entomol. 20: 71-76.

Losey, J. E. and R. F. Denno (1998) Positive predator-predator interactions: enhanced predation rates and synergistic suppression of aphid populations. Ecology 79: 21432153.

Losey, J. E. and R. F. Denno (1999) Factors facilitating synergistic predation: the central role of synchrony. Ecol. Appl. 9: 378-386.

Mackauer, M. (1990) Host discrimination and larval competition on solitary endoparasitoids. In Critical Issues in Biological Control (M. Mackauer, L. E. Ehler and J. Roland eds.). Intercept, Andover, UK, pp. 41-62.

Mackauer, M. and T. Finlayson (1967) The hymenopterous parasites (Hymenoptera: Aphidiidae et Aphelinidae) of the pea aphid in eastern North America. Can. Entomol. 99: 1081-1082.

Merritt, S. Z. (1996) Within-plant variation in concentrations of amino acids, sugar and sinigrin in phloem sap of black mustard, Brassica nigra (L.) Kock (Cruciferae). J. Chem. Ecol. 22: 1133-1145.

Milne, W. M. (1999) Evaluation of the establishment of Aphidius ervi Haliday (Hymenoptera: Braconidae) in lucerne aphid populations in New South Wales. Aust. J. Entomol. 38: 145-147.

Nagai, K. (1993) Studies on integrated pest management of Thrips palmi Karny. Spec. Bull. Okayama Pref. Agric. Exp. Stn. 82: 1-55.

Nakashima, Y., Birckett, M., Pye, B. J., Picket, J. and Powell, W. (2004) The role of semiochemicals in the avoidance of the seven-spot ladybird Coccinella septempunctata
(Coleoptera: Coccinellidae) by the aphid parasitoid, Aphidius ervi (Hymenoptera: Braconidae). J. Chem. Ecol. 30: 1103-1116.

Nakashima, Y. and N. Senoo (2003) Avoidance of ladybird trails by an aphid parasitoid Aphidius ervi: active period and effects of prior oviposition experience. Entomol. Exp. Appl. 109: 163-166.

Nielson, M. W. and J. A. Henderson (1959) Biology of Collops vittatus (Say) in Arizona, and feeding habits of seven predators of the spottes alfalfa aphid. J. Econ. Entomol. 52: $159-162$.

Ninkovic, V., S. A. Abassi and J. Pettersson (2001) The influence of aphid-induced plant volatiles on ladybird beetle searching behavior. Biol. Control 21: 191-195.

Powell, W., F. Pennacchio, G. M. Poppy and E. Tremblay (1998) Strategies involved in the location of hosts by parasitoid Aphidius ervi Haliday (Hymenoptera: Braconidae: Aphidiinae). Biol. Control 11: 104-112.

Powell, W., N. Wilding, P. J. Brobyn and S. J. Clark (1986) Interference between parasitoids (Hym.: Aphidiidae) and fungi (Entomophthorales) attacking cereal aphids. Entomophaga 31: 293-302.

Raymond, B., A. C. Darby and A. E. Douglas (2000) Intraguild predators and the spatial distribution of a parasitoid. Oecologia 124: 367-372.

Rice, W. R. (1989) Analyzing tables of statistical tests. Evolution 43: 223-225.

Rosenheim, J. A. (1998) Higher-order predators and the regulation of insect herbivore populations. Annu. Rev. Entomol. 43: 421-447.

Rosenheim, J. A., H. K. Kaya, L. E. Ehler, J. J. Marois and B. A. Jaffee (1995) Intraguild predation among biological control agents: theory and evidence. Biol. Control 5: 303-335.

Rosenheim, J. A., L. R. Wilhoit and C. A. Armer (1993) Influence of intraguild predation among generalist insect predators on the suppression of an herbivore population. Oecologia 96: 439-449.

Schellhorn, N. A. and D. A. Andow (1999) Cannibalism and interspecific predation: Role of oviposition behavior. Ecol. Appl. 9: 418-428.

Schepers, A. (1989) Chemical Control. In Aphids: Their Biology, Natural Enemies and Control. Vol. 2C (A. K. Minks and P. Harrewijn eds.). Elsevier, Amsterdam, pp. 89-122.

Senoo, N., Y. Ochiai and Y. Nakashima (2002) Seasonal abundance of primary parasitoids and hyperparasitoids associated with Acyrthosiphon pisum (Harris) and Acyrthosiphon kondoi Shinji (Homoptera: Aphididae) on alfalfa. Jpn. J. Appl. Entomol. Zool. 46: 96-98.

Siddiqui, W. H., C. A. Barlow and P. A. Randolph (1973) Effects of some constant and alternating temperatures on population growth of the pea aphid, Acyrthosiphon pisum (Homoptera: Aphididae). Can. Entomol. 105: 145-156.

Stern, V. N., R. A. J. Sharma and C. Summers (1980) Alfalfa damage from Acyrthocyphon kondoi and economic threshold studies in southern California. J. Econ. Entomol. 73: 145-148.

Summers, C. G. and R. L. Coviello (1984) Impact of 
Acyrthosiphon kondoi (Homoptera: Aphididae) on alfalfa: field and greenhouse studies. J. Econ. Entomol. 77: 1052-1056.

Sylvester, E. S. (1989) Viruses transmitted by aphids. In Aphids: Their Biology, Natural Enemies and Control. Vol. 2C (A. K. Minks and P. Harrewijn eds.). Elsevier, Amsterdam, pp. 65-87.

Takada, H. (1968) Aphidiidae of Japan (Hymenoptera). Insec. Matsu. 30: 67-124.

Takahashi, K. (1996) Studies on Coccinella septempunctata brucki Mulsant as a biological agent for controlling alfalfa aphids. Bull. Natl. Grassl. Res. Inst. 54: 17-77.

Takizawa, T., H. Yasuda and B. K. Agarwala (2000) Effects of parasitized aphids (Homoptera: Aphididae) as food on larval performance of three predatory ladybirds
(Coleoptera: Coccinellidae). Appl. Entomol. Zool. 35: 467-472.

Wells, M. L., R. M. McPherson and J. R. Ruberson (2001) Predation of parasitized and unparasitized cotton aphids (Homoptera: Aphididae) by larvae of two coccinellids. J. Entomol. Sci. 36: 93-96.

Wheeler, A. G. (1977) Studies on the arthropod fauna of alfalfa. VII. Predaceous insects. Can. Entomol. 109: 423-427.

Wheeler, A. G., J. T. Hayes, Jr. and J. L. Stephens (1968) Insect predators of mummified pea aphids. Can. Entomol. 100: 221-222.

Yasuda, H. and K. Shinya (1997) Cannibalism and interspecific predation in two predatory ladybirds in relation to prey abundance in the field. Entomophaga 42: 153-163. 